Creative commons User License: CC BY-NC-ND

Abstracted by: EBSCOhost, Electronic Journals Service (EJS),

Google Scholar, Directory of Open Access Journals (DOAJ),

Journal Seek, Scientific Commons,

Food and Agricultural Organization (FAO), CABI and Scopus
Journal of Agricultural Extension

Vol. XX (X) XXXXXX, 20XX

ISSN(e): 24086851; ISSN(Print); 1119944X

http://journal.aesonnigeria.org

http://www.ajol.info/index.php/jae

Email: editorinchief@aesonnigeria.org

\title{
Farmers and Extension Personnel View of Constraints to Effective Agricultural Extension Services Delivery in Oyo State, Nigeria \\ http://dx.doi.org/10.4314/jae.v20i2.15
}

\author{
Apantaku S.O. \\ Department of Agricultural Extension and Rural Development, \\ Federal University of Agriculture Abeokuta \\ Email: samapantaku@yahoo.com
}

\section{Aromolaran A. K.}

Department of Agricultural Extension and Rural Development, Federal University of Agriculture Abeokuta

Email: aromolaranak@funaab.edu.ng

\section{Shobowale, A. A.}

Department of Agricultural Education

Federal College of Education (Special), Oyo

Email: jokkyfun@yahoo.com

Phone No: 08062456382

Sijuwola, K. O.

Department of Agricultural Extension and Rural Development, Federal University of Agriculture Abeokuta

Email: sijuwolaolusola@gmail.com

\begin{abstract}
This study examined farmers' and extension personnel's View of constraints to effectiveness of agricultural extension services in Oyo State, Nigeria. Simple random sampling technique was used to select 100 farmers and 20 extension personnel. Data subjected to descriptive and correlation analyses were collected using questionnaire and interview schedule. Findings reveal that constraints to effectiveness of extension service include inadequate extension equipment/facilities $(\bar{x}=3.73)$, insufficient extension personnel $(\bar{x}=3.44)$ and poor planning of extension programme $(\bar{x}=2.8)$. About $54 \%$ of farmers perceived that extension service is ineffective while about $46 \%$ of extension personnel perceived it to be effective. Results show a weak correlation between personal characteristics of farmers and their perception towards the effectiveness of agricultural extension services $(r=$ $0.081, p<0.05$ ). It is concluded that constraints to effective extension service might not significantly affect the peoples' view of extension effectiveness, however, the less the constraints to extension services the better the perception of extension services.
\end{abstract}

Keywords: Extension, Effectiveness, Constraints, Perception and Agriculture 
Creative commons User License: CC BY-NC-ND

Abstracted by: EBSCOhost, Electronic Journals Service (EJS),

Google Scholar, Directory of Open Access Journals (DOAJ),

Journal Seek, Scientific Commons,

Food and Agricultural Organization (FAO), CABI and Scopus
Journal of Agricultural Extension

Vol. XX (X) XXXXXX, 20XX

ISSN(e): 24086851; ISSN(Print); 1119944X

http://journal.aesonnigeria.org

http://www.ajol.info/index.php/jae

Email: editorinchief@aesonnigeria.org

\section{Introduction}

Over the years, agricultural extension has been at the fore-front in the delivery of adequate information to farmers for increased productivity. According to Apantaku and Oyegunle (2016) and Agbamu (2007), agricultural extension service delivery all over the world has been concerned with communicating research findings and improved agricultural practices to farmers. Agricultural extension service is saddled with the responsibility of disseminating innovation that could transform agricultural production to ensure food security and economic development of agrarian community. The roles of extension today go beyond technology transfer and training of farmers but include assisting farmer to form groups, dealing with marketing issues, addressing public interest issues in rural areas such as resource conservation, health, monitoring of food security and agricultural production, food safety, nutrition, family education, and youth development and partnering with a broad range of service providers and other agencies (Ijeoma and Adesope, 2015).

Information and knowledge are very vital in agricultural development of any community and where they are poorly disseminated the community is at a risk of development. Omotayo (2005) observed that agricultural extension depends largely on information exchange between farmers and broad range of other actors who are the front line extension workers that are the direct link between farmers and other actors in the agricultural knowledge and information system (AKIS). ljeoma and Adesope (2015) opined that the mission of the extension service is to provide research-based information, educational programs, and technology transfer and needs of the people, enabling them to make informed decisions about their economic, social and cultural well-being. When farmers lack access to knowledge and information that would help them achieve maximum agricultural yield, or relevant information are not disseminated to them on agricultural activities/practices, they not only grope in the dark, but are driven by circumstances to migrate about in search of formal employment, as the only option for survival, which will eventually reduce agricultural activities in the country (Munyua, 2000).

Agricultural extension aims to disseminate relevant information for effectiveness and efficiency of agricultural activities but is confronted with certain constraints. Codjoe, 
Creative commons User License: CC BY-NC-ND

Abstracted by: EBSCOhost, Electronic Journals Service (EJS),

Google Scholar, Directory of Open Access Journals (DOAJ),

Journal Seek, Scientific Commons,

Food and Agricultural Organization (FAO), CABI and Scopus
Journal of Agricultural Extension

Vol. XX (X) XXXXXX, 20XX

ISSN(e): 24086851; ISSN(Print); 1119944X

http://journal.aesonnigeria.org

http://www.ajol.info/index.php/jae

Email: editorinchief@aesonnigeria.org

Brempong and Boateng (2013) identified inadequate interaction with researchers and extension agents; insufficient training programs for farmers; low general educational level of farmers and the delays in information delivery as pressing constraints to agricultural information in Ghana while Iwena (2008) identified absence of credit facilities, insufficient motivation of the personnel, inadequate resources, poor transportation network, high level of farmers' illiteracy and language barriers as some of the constraints faced by farmers in Nigeria. According to Munyua (2000) lack of access to basic agricultural knowledge and information by rural farmers can be assumed to be as a result of some constraints to effectiveness of agricultural extension activities which have made these farmers to stick to their old traditional methods of farming system and animal husbandry practice, hence resulting in poor crop and livestock productivity. Thus, this study was designed to investigate constraints to effectiveness of agricultural extension activities in Oyo East Local Government Area (LGA) of Oyo State.

\section{Objectives of the study}

The objectives of the study were to:

- describe personal characteristics of farmers and extension personnel in the study area;

- ascertain farmers' and extension personnel's perception towards the effectiveness of agricultural extension services;

- identify constraints to effectiveness of agricultural extension service in the study area; and

- identify possible solutions to the constraints affecting the effectiveness of agricultural services.

\section{Hypothesis of the Study}

There is no significant association between the personal characteristics of the respondents and their perception towards the effectiveness of agricultural extension services. 
Creative commons User License: CC BY-NC-ND

Abstracted by: EBSCOhost, Electronic Journals Service (EJS),

Google Scholar, Directory of Open Access Journals (DOAJ),

Journal Seek, Scientific Commons,

Food and Agricultural Organization (FAO), CABI and Scopus
Journal of Agricultural Extension

Vol. XX (X) XXXXXX, 20XX

ISSN(e): 24086851; ISSN(Print); 1119944X

http://journal.aesonnigeria.org

http://www.ajol.info/index.php/jae

Email: editorinchief@aesonnigeria.org

\section{Methodology}

\section{Study Area}

Oyo State is an inland state located in the south-west geopolitical zone of Nigeria. It was one of the three states carved out of the former Western state of Nigeria in 1967 and was later sub-divided into Osun and Oyo States in 1991. The state covers a total of 27,249 square kilometers of land mass. The State is bounded in the South by Ogun State and in the North by Kwara State, in the West is bounded partly by Ogun State and Republic of Benin. Oyo State consists of 33 LGAs. Some of the inhabitants are involved in farming activities such as planting of crops and rearing of livestock like cattle, goats, sheep, poultry; processing and marketing of farm produce, fishing, trading, particularly in the rural areas. The State has Agricultural Development Programme known as Oyo State Agricultural Development Programme (OYSADEP) where extension agents serve to disseminate information from research institutes through media, face-to-face, and/or group methods to the farmers (OYSADEP, 2015).

\section{Sampling procedure and data collection}

A multi stage sampling technique was used to select the respondents. A total of 100 farmers and 20 extension agents were selected for the study. The first stage involves random sampling of Oyo zone from four Agricultural Development Programme zones in Oyo State (OYSADEP, 2015); the second stage involves random sampling of two blocks from the selected zone to make four blocks; the third stage includes randomly sampling of one cell from the selected blocks to make four cells; 5 villages were selected from the chosen cells using simple random sampling to make 20 villages. From the selected villages, 5 farmers each were selected from the villages to make 100 farmers. Also, five extension personnel were randomly selected from the four blocks to make 20 extension personnel. Primary data were obtained using a questionnaire for extension personnel and interview schedule for farmers. 
Creative commons User License: CC BY-NC-ND

Abstracted by: EBSCOhost, Electronic Journals Service (EJS),

Google Scholar, Directory of Open Access Journals (DOAJ),

Journal Seek, Scientific Commons,

Food and Agricultural Organization (FAO), CABI and Scopus
Journal of Agricultural Extension

Vol. XX (X) XXXXXX, 20XX

ISSN(e): 24086851; ISSN(Print); 1119944X

http://journal.aesonnigeria.org

http://www.ajol.info/index.php/jae

Email: editorinchief@aesonnigeria.org

\section{Data Analysis}

Constraints to effectiveness of agricultural extension services were measured using High constraints (3), Low constraints (2) and Not a constraint (1) while perception of respondents was measured using a four (4) point likert scaling based on strongly Agreed (4), Agreed (3), Disagreed (2) and strongly Disagreed (1) for positive questions and based on strongly Agreed (1), Agreed (2), Disagreed (3) and Strongly Disagreed (5) for negative questions. The data collected were subjected to descriptive statistics such as frequency distribution, percentage, mean and chisquare analysis and Pearson Product Moment Correlation (PPMC).

\section{Results and Discussion}

\section{Personal characteristics of the respondents}

The result of the personal characteristics indicates that the majority (92\%) of farmers and all (100\%) extension agents were within the productive age of 25 years and above (Table 1). Onasanya (2009) classified productive age of farmers to be between 20 and 55 years. Also, Ezeh (2013) reported the productive age range of extension agents to be between 40 and 60 years of age. Ibitoye (2013) also asserted that only those farmers within the productive age group of 20-50 years are likely to possess the necessary strength to carry out farming operations. This implies that the majority of the respondents are still within the productive age. Table 1 also indicates that the males $(70 \%)$ constitute the majority of the respondents. This result agrees with Ibitoye (2013) who reported that more men were found in farming in Kogi State than women. The high percentage of male farmers in the state is expected because farming in Nigeria is done manually by the rural farmers and most of the major operations require a lot of energy which may be too tedious for most women.

Also, about 5\% (farmers) and 30\% (Extension agents) had secondary education while $25 \%$ (farmers) had primary education. Only $10 \%$ of the farmers and $70 \%$ of the extension agents had tertiary education. However, $21 \%$ (farmers) had no formal education and 39\% (farmers) had adult education. It is thus obvious that the levels of education of farmers in the state are generally high. This agrees with the work of Ibitoye and Onimisi, (2013) who found out that the levels of education of farmers are generally high in Kogi State. The level of education of extension agents agrees with 
Creative commons User License: CC BY-NC-ND

Abstracted by: EBSCOhost, Electronic Journals Service (EJS),

Google Scholar, Directory of Open Access Journals (DOAJ),

Journal Seek, Scientific Commons,

Food and Agricultural Organization (FAO), CABI and Scopus
Journal of Agricultural Extension

Vol. XX (X) XXXXXX, 20XX

ISSN(e): 24086851; ISSN(Print); 1119944X

http://journal.aesonnigeria.org

http://www.ajol.info/index.php/jae

Email: editorinchief@aesonnigeria.org

the findings of Ezeh (2013) who found out that the majority of extension agents completed post-secondary education

Table 1: Socio-economic characteristics of respondents

\begin{tabular}{|c|c|c|c|c|}
\hline \multirow{2}{*}{$\begin{array}{l}\text { Characteristics } \\
\text { Age (years) }\end{array}$} & \multicolumn{2}{|c|}{ Farmers(100) } & \multicolumn{2}{|c|}{ EA(20) } \\
\hline & & & & \\
\hline$<25$ & 8 & 8 & - & - \\
\hline$>25$ & 92 & 92 & 20 & 100 \\
\hline \multicolumn{5}{|l|}{ Sex } \\
\hline Male & 70 & 70.0 & 10 & 50 \\
\hline Female & 30 & 30.0 & 10 & 50 \\
\hline \multicolumn{5}{|l|}{ Religion } \\
\hline Islamic & 38 & 38.0 & 7 & 35 \\
\hline Traditional & 6 & 6.0 & - & - \\
\hline Christianity & 56 & 56.0 & 13 & 65 \\
\hline \multicolumn{5}{|l|}{ Educational level } \\
\hline No formal education & 21 & 21.0 & 1 & 5.0 \\
\hline Adult education & 39 & 39.0 & 5 & 25 \\
\hline Primary education & 25 & 25.0 & 1 & 5.0 \\
\hline Secondary education & 5 & 5.0 & 6 & 30 \\
\hline Tertiary education & 10 & 10.0 & 7 & 35 \\
\hline \multicolumn{5}{|l|}{ Marital status } \\
\hline Single & 19 & 19.0 & 6 & 30 \\
\hline Married & 61 & 61.0 & 14 & 70 \\
\hline Divorced & 10 & 10.0 & - & - \\
\hline Widowed & 10 & 10.0 & - & - \\
\hline \multicolumn{5}{|l|}{ Experience (years) } \\
\hline Less than 5years & 26 & 26.0 & 9 & 45 \\
\hline 5-10years & 35 & 35.0 & 3 & 15 \\
\hline Above 10years & 39 & 39.0 & 8 & 40 \\
\hline \multicolumn{5}{|l|}{ Household income } \\
\hline less than $\# 100,000$ & 17 & 17.0 & 8 & 40 \\
\hline$\$ 100,000-\$ 500,000$ & 12 & 12.0 & 3 & 15 \\
\hline Above $\$ 500,000$ & 71 & 71.0 & 7 & 35 \\
\hline
\end{tabular}

EA: Extension Agents, \%: percentage. 
Creative commons User License: CC BY-NC-ND

Abstracted by: EBSCOhost, Electronic Journals Service (EJS),

Google Scholar, Directory of Open Access Journals (DOAJ),

Journal Seek, Scientific Commons,

Food and Agricultural Organization (FAO), CABI and Scopus
Journal of Agricultural Extension

Vol. XX (X) XXXXXX, 20XX

ISSN(e): 24086851; ISSN(Print); 1119944X

http://journal.aesonnigeria.org

http://www.ajol.info/index.php/jae

Email: editorinchief@aesonnigeria.org

\section{Perception of farmers and extension personnel towards the effectiveness of agricultural extension services}

Result shows that the majority (86\%) of the farmers and extension agents $(80 \%)$ indicated that insufficient equipment needed to disseminate information reduces the rate of effectiveness of extension services. This agrees with the findings of Gwary, Donye, Wakawa and Shallangwa (2013) that lack of insufficient equipment was a major factor that hinders the delivery of extension services to the respondents. The majority (94\%) of the farmers and extension agents (80\%) agreed that lack of motivation towards extension personnel makes the extension service ineffective. Also, about $53 \%$ of the farmers and $80 \%$ of extension agents were of the opinion that agricultural extension services are good and help to improve farming activities; and about $94 \%$ farmers and three quarter of extension agents agreed that agricultural extension services help in training farmers on better ways of farming.

Also the tables indicate that about $97 \%$ of farmers and $70 \%$ of extension agents disagreed that poor transportation network does not affect extension service delivery; the majority $96 \%$ of the farmers and three quarter of extension agents disagreed that extension services can be effective without government support. The results further showed that about $95 \%$ of farmers and $75 \%$ of extension agents were against the statement that insufficient extension personnel do not hinder the effectiveness of extension service delivery. Lastly, about $94 \%$ of farmers and $60 \%$ of extension agents disagreed that insufficient fund is not a barrier for the effectiveness of agricultural extension service. This is an indication that insufficient fund is a barrier to effectiveness of agricultural extension service. This agrees with the report of Agbamu (2005) that Nigeria extension service is bedevilled by several problems which include inadequacy and instability of funding and poor logistic support for field staff. Omotayo (2004) reported that since the late 1990's, inadequate funding has led to the virtual collapse of research and extension institutions that provided services to small farmers and rural communities in Nigeria. 
Creative commons User License: CC BY-NC-ND

Abstracted by: EBSCOhost, Electronic Journals Service (EJS),

Google Scholar, Directory of Open Access Journals (DOAJ),

Journal Seek, Scientific Commons,

Food and Agricultural Organization (FAO), CABI and Scopus
Journal of Agricultural Extension

Vol. XX (X) XXXXXX, 20XX

ISSN(e): 24086851; ISSN(Print); 1119944X

http://journal.aesonnigeria.org

http://www.ajol.info/index.php/jae

Email: editorinchief@aesonnigeria.org

\section{Table 2: Distribution of farmers according to perception towards the effectiveness of agricultural extension services}

Variables Mean

\footnotetext{
Agricultural extension services are good and help to improve farming 2.5

activities.

Agricultural extension services help in training farmers on better ways of 3.3

farming.

Lack of motivation towards extension personnel makes the extension $\quad 3.4$

service ineffective.

Insufficient aids needed to

disseminate information reduce the rate of effectiveness of extension services.

Poor transportation network does not affect

extension service delivery.

Extension services can be effective without

government support.

Insufficient extension personnel do not hinder the effectiveness of

extension service delivery.

Insufficient fund is not a barrier for the effectiveness of agricultural

extension service.
}

\section{Table 3: Distribution of extension personnel according to perception towards the effectiveness of agricultural extension services}

Variables $\quad$ Mean

\begin{tabular}{ll}
\hline Agricultural extension services is good and helps to & 2.9 \\
improve farming activities & \\
Agricultural extension services helps in training farmers on better ways of farming & 3.4 \\
Lack of motivation towards extension personnel makes the extension service & 3.2 \\
ineffective & 3.0 \\
Insufficient aids needed to disseminate information reduce the rate of effectiveness & 3.9 \\
extension services in Oyo east local government & 3.1 \\
Poor transportation network does not affect extension & \\
service delivery & \\
Extension services can be effective without government & \\
Support & 2.8 \\
Insufficient extension personnel does not hinder the effectiveness of service deliver & 0.6 \\
Lack of capital does not affect the effectiveness of extension service delivery &
\end{tabular}


Creative commons User License: CC BY-NC-ND

Abstracted by: EBSCOhost, Electronic Journals Service (EJS),

Google Scholar, Directory of Open Access Journals (DOAJ),

Journal Seek, Scientific Commons,

Food and Agricultural Organization (FAO), CABI and Scopus
Journal of Agricultural Extension

Vol. XX (X) XXXXXX, 20XX

ISSN(e): 24086851; ISSN(Print); 1119944X

http://journal.aesonnigeria.org

http://www.ajol.info/index.php/jae

Email: editorinchief@aesonnigeria.org

\section{Constraints to effectiveness of agricultural extension services}

Major constraints to effectiveness of extension service include inadequate extension equipment $(\bar{x}=3.73)$, insufficient extension personnel $(\bar{x}=3.44)$ and improper planning of extension programme $(\bar{x}=3.3)$ (Table 4). This agrees with the findings of Gwary, Donye, Wakawa and Shallangwa (2013) that lack of or inadequate extension equipment was a major factor that hinders the delivery of extension services to the respondents

Table 4: Distribution of the respondents according to perceived constraints to effectiveness of agricultural extension services

\begin{tabular}{ll}
\hline Variables & Mean \\
& \\
\hline Improper planning of extension programme & 3.3 \\
Large scope of area to cover by extension personnel & 2.4 \\
Insufficient extension personnel & 3.44 \\
Inadequate extension equipment & 3.73 \\
needed to disseminate information & \\
Lack of motivation & 2.5 \\
Insufficient fund from the government & 2.3 \\
\hline
\end{tabular}

\section{Solution to the constraints to effectiveness of agricultural extension services}

Results from the findings (Table 5) indicate that the majority of the respondents suggested the following as solutions to constraints to effectiveness of agricultural extension services; Agricultural extension centres should be equipped with instructional materials for disseminating agricultural information or new innovations, Funds should be provided for extension personnel in order to work effectively, Extension programmes should be planned well before been taking out to the farmers, Employment of more extension personnel to ease the effectiveness of extension service delivery, the area of scope to be covered by extension personnel should not be too wide for individual extension personnel so as to promote effective agricultural extension service delivery and Farmers should be ready to work with the extension personnel and as well accept the services given to them. 
Creative commons User License: CC BY-NC-ND

Abstracted by: EBSCOhost, Electronic Journals Service (EJS),

Google Scholar, Directory of Open Access Journals (DOAJ),

Journal Seek, Scientific Commons,

Food and Agricultural Organization (FAO), CABI and Scopus
Journal of Agricultural Extension

Vol. XX (X) XXXXXX, 20XX

ISSN(e): 24086851; ISSN(Print); 1119944X

http://journal.aesonnigeria.org

http://www.ajol.info/index.php/jae

Email: editorinchief@aesonnigeria.org

Table 5: Distribution of respondents according to the solutions to the constraints to effectiveness of agricultural extension services

\begin{tabular}{lc}
\hline Variables & Mean \\
\hline Agricultural extension centres should be equipped with & 3.84 \\
instructional materials for disseminating agricultural information or new innovations. \\
Funds should be provided for extension personnel in order to \\
work effectively. \\
Extension programmes should be planned well before been taking out to the farmer 3.61 \\
Employment of extension personnel to ease the effectiveness of extension service 3.35 \\
delivery. \\
The scope of area to be covered by extension personnel should not be too wide for 3.41 \\
individual extension personnel so as to promote effective agricultural extension \\
service delivery. \\
Farmers should be ready to work with the extension personnel and as well accept th 3.46 \\
services given to them.
\end{tabular}

Relationship between the personal characteristic of respondents and perception towards the effectiveness of agricultural extension service

In Table 6, result of correlation analysis showed that the age $(r=0.20)$ of the rural farmers has an effect on their perception towards the effectiveness of agricultural extension services at $(P<0.05)$. Table 6 showed that the personal characteristics of rural farmers has no significant $(P<0.05)$ relationship with their perception towards the effectiveness of agricultural extension services with $\operatorname{sex}\left(x^{2}=0.93\right)$, religion $\left(x^{2}=0.67\right)$, educational level $\left(x^{2}=4.85\right)$ and marital status $\left(x^{2}=1.57\right)$. This implies that the personal characteristics of rural farmers in Oyo East LGA make them to have a favourable perception on the effectiveness of agricultural extension service in the study area. Also, the result of chi-square revealed that the personal characteristics of the extension personnel has no significant effect on their perception towards the effectiveness of agricultural extension services $(P<0.05)($ Table 8$)$

Table 6: Relationship between personal characteristics of farmers and their perception towards the effectiveness of agricultural extension service delivery

\begin{tabular}{ll}
\hline Variables & $\mathbf{r}$ \\
\hline Age & $0.20^{*}$ \\
Farming experience & 0.09 \\
Income & 0.75 \\
\hline $\mathrm{P} \leq 0.05 ;$ r: correlation coefficient
\end{tabular}


Creative commons User License: CC BY-NC-ND

Abstracted by: EBSCOhost, Electronic Journals Service (EJS),

Google Scholar, Directory of Open Access Journals (DOAJ),

Journal Seek, Scientific Commons,

Food and Agricultural Organization (FAO), CABI and Scopus
Journal of Agricultural Extension

Vol. XX (X) XXXXXX, 20XX

ISSN(e): 24086851; ISSN(Print); 1119944X

http://journal.aesonnigeria.org

http://www.ajol.info/index.php/iae

Email: editorinchief@aesonnigeria.org

Table 7: Relationship between the personal characteristics of farmers and perception of the effectiveness of agricultural extension service delivery

\begin{tabular}{lllll}
\hline Variables & $\mathrm{x}^{2}$ & $\mathbf{d f}$ & P-values & Decisions \\
\hline Sex & 0.93 & 1 & 0.34 & N.S \\
Religion & 0.67 & 2 & 0.71 & N.S \\
Education & 4.85 & 4 & 0.30 & N.S \\
Marital status & 1.57 & 3 & 0.67 & N.S \\
Type of Farming & 0.67 & 2 & 0.72 & N.S \\
Other occupation & 3.32 & 4 & 0.51 & N.S \\
\hline
\end{tabular}

Level of Significant $(\mathrm{P}<0.05)$, df: degree of freedom, $\mathrm{x}^{2}$ : chi-square

Table 8: Relationship between socio-economic characteristics of extension personnel and perception of the effectiveness of agricultural extension services

\begin{tabular}{lllll}
\hline Variables & $\mathrm{x}^{2}$ & Df & P-values & Decisions \\
\hline Sex & 1.82 & 1 & 0.18 & N.S \\
Religion & 0.64 & 1 & 0.42 & N.S \\
Educational level & 2.84 & 4 & 0.59 & N.S \\
Marital status & 0.09 & 1 & 0.77 & N.S \\
Other occupation & 1.95 & 3 & 0.58 & N.S \\
\hline
\end{tabular}

Level of Significant $(P<0.05)$, df: degree of freedom, $x^{2}$ : chi-square

Table 9: Relationship between the personal characteristics of extension personnel and perception towards the effectiveness of agricultural extension services

\begin{tabular}{llll}
\hline Variables & $\mathbf{r}$ & P-values & Decisions \\
\hline Age & 0.19 & 0.42 & N.S \\
Farming experience & 0.07 & 0.78 & N.S \\
Income & 0.06 & 0.79 & N.S \\
\hline
\end{tabular}

Level of Significant $(P<0.05)$, r: correlation coefficient

\section{Conclusion and Recommendations}

Rural farmers have favourable perception about the effectiveness of agricultural extension services. The farmers' perceived constraints are insufficient extension personnel; inadequate extension equipment and facilities to disseminate information. Also, the major constraints to effectiveness faced by the extension personnel are improper planning of extension programmes and inadequate extension equipment or 
Creative commons User License: CC BY-NC-ND

Abstracted by: EBSCOhost, Electronic Journals Service (EJS),

Google Scholar, Directory of Open Access Journals (DOAJ),

Journal Seek, Scientific Commons,

Food and Agricultural Organization (FAO), CABI and Scopus
Journal of Agricultural Extension

Vol. XX (X) XXXXXX, 20XX

ISSN(e): 24086851; ISSN(Print); 1119944X

http://journal.aesonnigeria.org

http://www.ajol.info/index.php/jae

Email: editorinchief@aesonnigeria.org

facilities to disseminate information. Based on the findings of the study, the following recommendations were made: more extension personnel should be employed and fortified with necessary equipment and facilities to enhance effective dissemination of information for transformation of agriculture in the state and the nation at large, proper planning of extension programmes should be made before its being carried out and provision of equipment for dissemination of information should be done by the government to enhance effective dissemination of information to the rural farmers. Extension personnel should be well motivated to enhance them to work more efficiently.

\section{References}

Agbamu, J. U. (2005). Problem and Prospect of Agricultural Extension Services in Development Countries in Agricultural Extension. In: Nigeria S. F. Afolayan (Ed) Ilorin AESON, P. 159-169

Agbamu, J.U. (2007). Essentials of Agricultural Communication in Nigeria. Malthouse Press Limited Lagos. pp. 20-24, 91-93.

Apantaku, S.O. and Oyegunle, J. O. (2016). Reports from the Field: Challenges of Agricultural Extension Agents in Ogun State Nigeria. Paper Presented at the $7^{\text {th }}$ GFRAS. (Global Forum for Rural Advisory Services) Annual Meeting. 3-6 Oct. Fini Hotel, Limbe, Cameroon.

Codjoe, F.N.Y., Brempong, S.A., Boateng, D.O. (2013). Constraints facing cocoa based agricultural knowledge and information system in Ghana: Perception of cocoa farmers in the Eastern Region of Ghana. American Open Journal of Agricultural Research. 1 (8), $1-11$.

Ezeh, A N. (2013). Extension agents' access and utilization of information and communication technology (ICT) in extension service delivery in South East Nigeria. Journal of Agricultural Extension and Rural Development. 5 (11). 266 276.

Gwary, M. M., Donye, A. O., Wakawa, R. C. and Shallangwa, M. D. (2013). Constraints to extension service delivery in the production, processing and marketing of gum Arabic in Magumeri Local Government Area of Borno State, Nigeria. Agriculture and Biology Journal of North America. 4(2): 126 131.

Ibitoye, S.J. 2013. Survey of the Performance of Agricultural Cooperative Societies in Kogi State, Nigeria. Eur. Scientific J. (ESJ), 8928: 98-114.

Ibitoye, S.J. and Onimisi, J.A. (2013). Influence of training on farmer's productivity in poultry production in Kogi State, Nigeria. International Journal of Poultry Science, 12 (4): 239-244.

ljeoma, M. C. and O. M. Adesope (2015). Effect of personality types of extension personnel on their job performance in Rivers State Agricultural Development Programme. Journal of Agricultural Extension. 19 (1), 1 - 13 
Creative commons User License: CC BY-NC-ND

Abstracted by: EBSCOhost, Electronic Journals Service (EJS),

Google Scholar, Directory of Open Access Journals (DOAJ),

Journal Seek, Scientific Commons,

Food and Agricultural Organization (FAO), CABI and Scopus
Journal of Agricultural Extension

Vol. XX (X) XXXXXX, 20XX

ISSN(e): 24086851; ISSN(Print); 1119944X

http://journal.aesonnigeria.org

http://www.ajol.info/index.php/jae

Email: editorinchief@aesonnigeria.org

Iwena, A.O. (2008). Essential Agricultural Science for Senior Secondary School. Tonad publishers Itd.pg 337.

Munyua, H. (2000). Application of Information Communication Techniques in the Agricultural Sector in Africa: A Gender Perspective. In: Rathgeber, E, and Adera, E.O (Eds). Gender \& Information Revolution in Africa. IDRC\&ECA. 85123.

Omotayo A (2004). Institutional arrangement for effective participation of the private sector and other non-government Service Providers - Extension Delivery in Nigeria. In: Adedoyin SF, Adeokun OA (Eds.). Institutional Frameworks and Processes for Enhancing Effectiveness of Extension Service. Proceedings of the $1^{\text {st }}$ South West AESON Workshop, pp. 16-23.

Omotayo, O.M. (2005). ICT and agricultural extension: Issues in transferring agricultural technology in developing countries. Proceedings of 3rd Annual Conference of AESON Ilorin. pp. 132-135.

Onasanya, A.S. (2009). Perceived Effect of Training Related Health Problems of farmer's productivity in Yewa North Area of Ogun State, Nigeria. Unpublished M. Phil Thesis. Faculty of Agricultural, University of Ibadan.

Oyo State Agricultural Development Programme (OYSADEP). (2015). Staff record of Oyo State Agricultural Development Programme (OYSADEP). 